\title{
Fundamentals of neuromarketing: What is it all about?
}

Aida Azlina Mansor ${ }^{1 *}$, and Salmi Mohd Isa ${ }^{2}$

${ }^{1}$ Faculty of Business and Management, Universiti Teknologi MARA, Selangor, Malaysia.

${ }^{2}$ Graduate School of Business, Universiti Sains Malaysia, Penang, Malaysia.

* Correspondence: aidaazlina@uitm.edu.my; Tel.: +603-3258 5030

Received: 17 September 2020; Accepted: 30 November 2020; Published: 3 December 2020

Edited by: Pike-See Cheah (Universiti Putra Malaysia)

Reviewed by: Tahamima Begum (Universiti Sains Malaysia);

Muhamad Kamal Mohammed Amin (Universiti Teknologi Malaysia)

https://doi.org/10.31117/neuroscirn.v3i4.58

\begin{abstract}
Neuromarketing has become a central marketing issue in the new global economy. The term neuromarketing is a combination of neuroscience and marketing. This new concept provides new insights and powerful techniques in marketing research, especially on consumer analysis. The central concept of neuromarketing is strongly related to brain activities, understanding the consumers' subconscious mind, explaining consumers' preferences, motivations, and expectations, and predicting consumers' behavior. Neuromarketing is not to replace traditional marketing methods, but rather to provide unique and complementary insights. This paper focuses on the growing field of neuromarketing and aims to explain the fundamental concepts of neuromarketing to ensure that its unexplored practical usefulness can positively contribute to the field of marketing. Therefore, this review will help researchers to develop effective approaches further, to provide better and more efficient services to consumers through the use of scientific methods to understand how consumers respond to marketing campaigns.
\end{abstract}

Keywords: neuromarketing; neuroscience; neuroscience tools; consumer behavior

C2020 by Mansor \& Mohd Isa for use and distribution in accord with the Creative Commons Attribution (CC BYNC 4.0) license (https://creativecommons.org/licenses/by-nc/4.0/), which permits unrestricted non-commercial use, distribution, and reproduction in any medium, provided the original author and source are credited.

\subsection{INTRODUCTION}

Neuromarketing is a field of study concerning the application of neuroscientific methods to analyze and understand human behavior related to markets and marketing activities (Lee et al., 2007; Vecchiato et al., 2011a). This is an overview review of neuromarketing from the perspective of social sciences. Basic introduction of neuromarketing is fundamental to gain basic knowledge, especially from a non-science background. Therefore, neuroscience can be applied to marketing to understanding the consumer better. It will allow marketing researchers to have a better understanding of the minds of consumers and the role of consumer emotions in decision making. With the help of neuroscience, it is possible to get a better understanding of consumers' needs, which can assist marketers in improving their marketing strategies (Hubert \& Kenning, 2008). For that reason, neuroscience finds its place in marketing research.

The term neuromarketing was first introduced in 2002 by Professor Ale Smitds, from Erasmus University in Rotterdam, as a reference to the application of neuroimaging techniques in marketing research. He explained how neuroscience tools such as Functional Magnetic Resonance Imaging (fMRI) scanner can be used to measure consumers' subconscious processes such as emotions, needs, and wants; and to stimuli, such 
as pictures and sound. Initially, the term neuromarketing was first appeared in marketing research using fMRI by Bright House, which is an advertising company (Fisher et al., 2010). Neuromarketing tools had been available since the early 1960s when Herbert Krugman began using pupil metering tools that measure spontaneous pupil enlargement as an indication of interest for consumers as in print of packages and Galvanic skin response (GSR) as a symbol of customer emotional reaction to advertisement (Sutherland, 2007). Meanwhile, the first use of $\mathrm{FMRI}$ as a marketing tool was reported by Gerry Zaltman of Harvard University in the late 1990s (Lewis \& Bridger, 2005).

Conceptually, neuromarketing is composed of three primary disciplines or fields - neuroscience, marketing, and psychology; and its core function is to explore and understand consumer subconscious mind for the meaningful decision-making process (Javor et al., 2013; Khushaba et al., 2013; Sebastian, 2014). The interaction between marketing and neuroscience has resulted in a series of questions specifically on how does a brand, a product, an advertisement, or a decision making affects our brain and our behavior (Oliveira et al., 2014). The connection between marketing and psychology leads to consumer behavior, which involves a complicated mental process as well as physical activity such as decision making. To obtain an in-depth understanding and knowledge of the decision-making process, neuroscience is embedded in the two areas. For that reason, the term neuromarketing exists as an interaction between the three disciplines discussed earlier. Steidl (2012) agreed that the foundation of neuromarketing is to allow marketers to gain deeper insights into how the consumer's brain works. Figure 1 illustrates the collaboration between three main fields in neuromarketing. To ensure that neuromarketing study is effective and its application is operational, it should involve the three main areas.

As the subject of neuromarketing continues to grow, the findings are becoming increasingly important in delivering meaningful data to companies. The data gained from neuromarketing will provide information on consumer preferences for the products and brands and help to develop strategic advertising campaigns and design new products or shopping environments.

\subsection{THE CONCEPT OF NEUROMARKETING}

An increasing number of publications acknowledge the value of neuromarketing leading to a large amount of literature on neuromarketing. The iconic and popular application of neuromarketing in the early days was the taste test between Coke and Pepsi in an unpublished experiment by Read Montague (McClure et al., 2004). In the challenge, the respondents were asked to blindly taste both Coke and Pepsi. fMRI was used to scan the brain of respondents to see if they like Coke over Pepsi. Before the test started, the participants said they favored Coke over Pepsi, but preferred Pepsi over Coke during the blind test taste. McClure et al. (2004) noticed that Coke's marketing strategy was much more advanced than Pepsi and unavoidably led the customer to believe that Coke is much favored. The outcome of this study shows that consumers often convey something else, even though they have another choice subconsciously (Babu \& Vidyasagar, 2012). The theory of neuroscience can therefore be used in marketing research to explore the response of consumers to stimuli effectively.

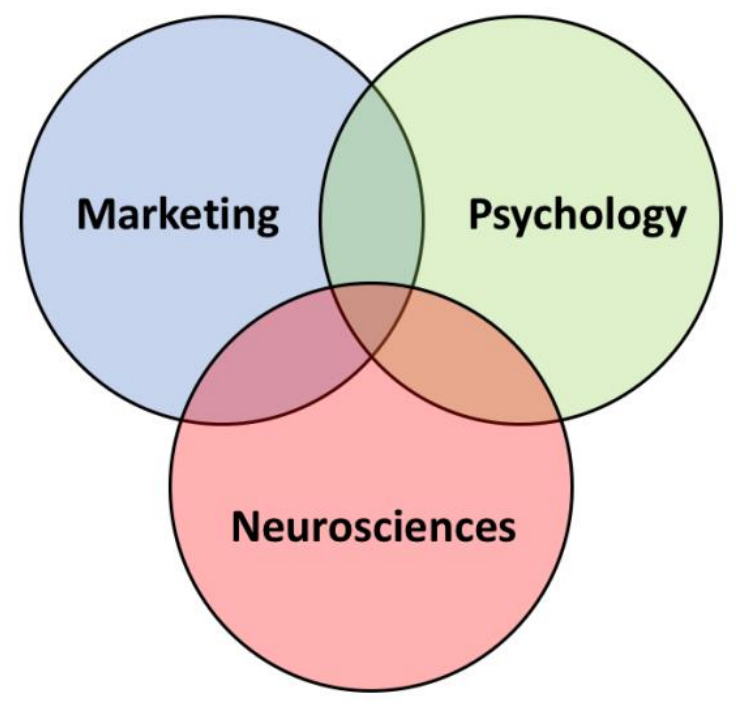

Figure 1: Basic areas in neuromarketing

Neuromarketing provides powerful insight and technological advances in market research, especially in the study of consumer behavior (Genco et al., 2013). This is supported by Colaferro and Crescitelli (2014) who mentioned that neuromarketing offers a wide range of expertise, adding the subconscious behavior information to the consumer's decision-making process. Neuromarketing study therefore can measure constructs such as emotional engagement, memory retention, purchase intention, novelty, awareness, attention of the consumers, branding, product design and innovation, advertising effectiveness, consumer decision making, online experiences, and entertainment effectiveness (Sebastian, 2014; Genco et al., 2013). 
The results from the neuromarketing study are impactful and help researchers to understand consumers better. Neuromarketing can be a powerful tool in predicting consumer habits when neuromarketing results are combined with other qualitative data. By complementing and supporting traditional research methods, neuromarketing can also help the marketers to have a better understanding of consumer preferences (Rehman et al., 2016). Neuromarketing has a bright future. By applying neuromarketing, marketers can strategize and create smarter marketing that will boost the effectiveness of their marketing effort.

\subsection{NEUROMARKETING TOOLS}

Traditionally, for decades, organizations have to depend mostly on conventional self-administered surveys, experiments, and focus groups to measure the wants, needs, and attitudes of consumers (McDowell \& Dick, 2013; Gidlöf et al., 2013). Undeniably, this method has produced good results and has helped organizations in designing their strategic marketing plans. One of the major weaknesses of the traditional market research tool is its dependence on the respondents to provide honest feedback, and in the inability of their findings to observe the subconscious part of the consumers' mind. Most of the traditional research methods only measure the conscious part of the consumer decision-making process, because it is easy to measure and to understand. This traditional marketing method fails to gather consumers' subconscious information (Calvert \& Brammer 2012; Spanjaard et al., 2014) and it leads to the poor prediction of consumer behavior consequently, there will be a mismatch between the market research findings and the actual behavior displayed by the consumer at the point of purchase (Agarwal \& Dutta, 2015). As stated by Lowenstein (2019), it is essential to know what is inside the consumer's mind so that marketers can shape, or modify, and communicate the messages to the consumer successfully.

The basic tools used in neuromarketing can be divided into three categories; tools that record the metabolic activity of the brain, tools that record the electric activity of the brain, and tools without recording brain activity (Zurawicki, 2010; Kenning et al., 2007; Calvert et al., 2014). Each of the tools has specific strengths and weaknesses, which make them more or less appropriate for different research situations. Neuromarketing measures responses of the consumer's brain to marketing messages using neuroimaging technologies by creating pictures or images of activity within the brain (Ariely \& Berns, 2010; Palokangas et al., 2012). The basic techniques used in neuromarketing are Electroencephalography (EEG), Magneto Encephalography (MEG), Positron Emission Tomography (PET), and Functional Magnetic Resonance Imaging (fMRI) that provide the best proof of how the brain processes the knowledge behind purchasing choices (Sebastian 2014; Suomala et al., 2012; Fugate, 2007). Figure 2 presents the available neuromarketing instruments (Bercea, 2012).

Currently, only fMRI, EEG, and MEG are considered as well-established and non-invasive methods for measuring and mapping consumers' brain responses to marketing stimuli. Due to their non-invasive nature, these three methods - fMRI (Mostafa, 2014; Sands \& Sands, 2012) EEG (Slavutskaya et al., 2014; Telpaz et al., 2015) and MEG (Vecchiato et al., 2011b) are used in most of the studies conducted within the field of neuromarketing. However, many social science researchers find it difficult to fully understand these research outcomes because most of the results are presented in technical clinical terminologies. The available neuroscience tools are technologically advanced and expensive. Researchers and marketers are advised to study and understand their marketing objectives, the functions of each tool, how it works, how to analyze the data, and how to apply the data to the marketing strategies. Therefore, to fill the gap and at the same time to offer the awareness that neuromarketing is not something uncommon in the marketing environment, more publications and research on neuromarketing is required.

\subsection{MARKETING FROM NEUROMARKETING PERSPECTIVES}

The literature on marketing mix from neuromarketing perspectives is multidimensional. Neuromarketing is mainly used to get new information about consumers' preferences regarding products and services, and the marketing mix is suitable for the application. Considerable research has already explored marketing mix and reported findings from traditional conventional research method, however, recent advances in neuroimaging technology, have encouraged many researchers to explore more details on marketing functions from the neuroscience perspective (Fehse et al., 2017; Lepping et al., 2015; Samsuri et al., 2018). 


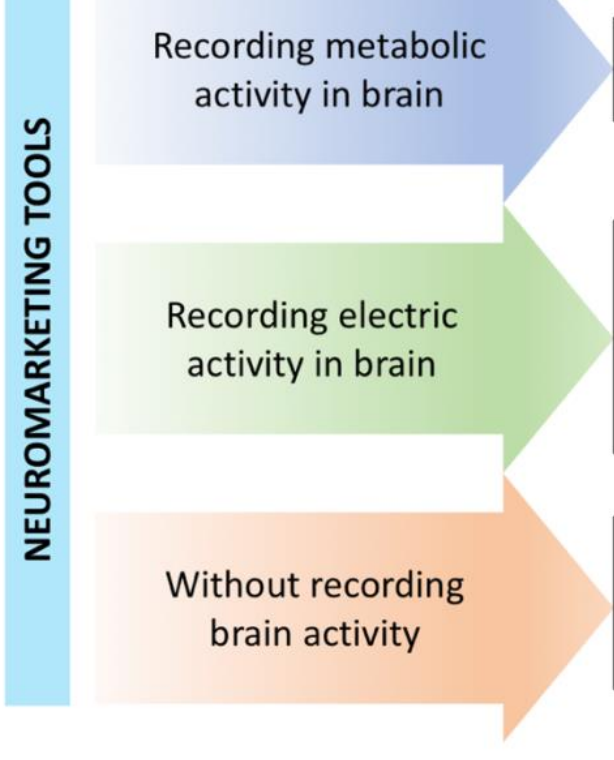

- Functional Magnetic Resonance Imaging (fMRI)

- Positron Emission Tomography (PET)

- Transcranial Magnetic Stimulation (TMS)

- Steady State Topography

- Electroencephalography (EEG)

- Event-related potential (ERP)

- Magnetoencephalography (MEG)

- Facial Coding - Skin Conductance

- Implicit Association Test - Eye Tracking

- Facial Electromyography

- Measuring Physiological Response

Figure 2: Neuromarketing tools

One of the main benefits of neuroscience in the marketing context it might improve the marketing message for existing products and provide insights into how products are valued before they even exist in the marketplace (Telpaz et al., 2015). The adoption of neuroscience methods and forms of neuromarketing research in previous literature is summarized in Table 1. Table 1 shows the conceptualization of marketing into neuroscience fields. The findings of this study have shown that most of the papers have used neuromarketing methods in business research.

Table 1: Neuromarketing study

\begin{tabular}{|c|c|c|c|}
\hline Authors & Context & $\begin{array}{l}\text { Neuroscience } \\
\text { tools }\end{array}$ & $\begin{array}{c}\text { Marketing } \\
\text { mix } \\
\text { concept }\end{array}$ \\
\hline $\begin{array}{l}\text { Ohme et al.., } \\
\underline{2010}\end{array}$ & TV ads & EEG & Product \\
\hline $\begin{array}{l}\text { Reutskaja et al., } \\
\underline{2011}\end{array}$ & Snacks & ET & Product \\
\hline $\begin{array}{l}\text { Khushaba et al., } \\
2013\end{array}$ & Crackers & Eye tracking & Product \\
\hline $\begin{array}{l}\text { Ravaja et al., } \\
\underline{2013}\end{array}$ & $\begin{array}{l}\text { Grocery } \\
\text { products }\end{array}$ & EEG & Price \\
\hline $\begin{array}{l}\text { Bebko et al., } \\
2014\end{array}$ & $\begin{array}{c}\text { Advertise } \\
\text { ment }\end{array}$ & ET & Product \\
\hline $\begin{array}{l}\text { Lepping et al., } \\
2015\end{array}$ & Food & fMRI & Product \\
\hline $\begin{array}{l}\text { Telpaz et al., } \\
\underline{2015} \\
\end{array}$ & $\begin{array}{l}\text { Consumer } \\
\text { s goods }\end{array}$ & EEG & $\begin{array}{c}\text { Product } \\
\text { Price }\end{array}$ \\
\hline Al-Kwifi, 2016 & $\begin{array}{l}\text { Soft drink } \\
\& \text { bottles } \\
\text { filled with } \\
\text { water }\end{array}$ & fMRI & Product \\
\hline
\end{tabular}

\begin{tabular}{lccc}
\hline$\frac{\text { Kühn et al., }}{2016}$ & $\begin{array}{c}\text { Chocolate } \\
\text { bar }\end{array}$ & fMRI & Product \\
\hline$\underline{\text { Samsuri et al., }}$ & Car & EEG & Product \\
\hline$\underline{\text { Clement et al., }}$ & $\begin{array}{c}\text { Consumer } \\
\text { s goods }\end{array}$ & ET & $\begin{array}{c}\text { Product } \\
\text { Price }\end{array}$ \\
\hline$\underline{\text { Fense et al., }}$ & $\begin{array}{c}\text { Organic } \\
\text { food }\end{array}$ & fMRI & Product \\
\hline
\end{tabular}

There is limited application of neuroscience in neuromarketing study in Malaysia because the application and concept are still new in the Malaysian context. However, neuromarketing is nothing new in other parts of the world. There is only a few researches available in the Malaysian context, on the topic of consumer cognitive response and gaze behavior to the display design of auto dealer's advertisement (Samsuri et al., 2018). The findings of the study reveal that from an event-related potential (ERP) and Eye Tracking, automotive companies can better understand the conscious and unconscious thoughts of customers and tailor relevant marketing strategies. And yet another analysis of neuromarketing should be published.

\subsection{ETHICS}

Ethical codes are the ethical standards, and researchers and advertisers must comply with the laws stipulated in ethical codes (Arlauskaite, \& Sferle, 2013). Neuromarketing study raises many ethical concerns that researchers need to answer. Therefore, the Neuromarketing Science and Business Association 
(NMSBA) Code of Ethics for the Application of Neuroscience in Business is being used. This code aims to ensure that neuromarketing research meets the highest ethical standards. The code addresses three main aspects which are to establish public confidence in the credibility of neuro marketers; to protect the privacy of participants and to protect neuromarketing purchasers as stipulated by Neuromarketing Science \& Business Association. However, discussions on neuromarketing and ethics have focused on consumer manipulation and lack of transparency (Fisher et al., 2010; Hensel et al., 2017). Neuromarketing poses some ethical concerns, for example, the need to protect test participants, the need to prevent vulnerable groups from manipulating them, and the need not provide the public with misleading knowledge (Nyoni \& Bonga, 2017; Lim, 2018). The ethical problem may arise because targeted consumers lack knowledge, consent, and understanding (Wilson et al., 2008). This to ensure that the right and privacy of consumers are not violated.

\subsection{CONCLUSION}

Neuromarketing offers valuable resources for marketing research, even though it faces many challenges, although it is still young in marketing research. The Neuromarketing foundation will allow advertisers to improve their understanding of the functioning of customer behavior. This process is expected to lead to more effective customer segmentation, leading, in turn, to better product marketing by taking account of individual product and brand preferences and general consumer behavior. Hence, a neuromarketing strategy is difficult to follow because of a lack of experience, high costs, and lack of accessibility to resources. In summary, an analysis of the value of neuromarketing in the conceptualization of customer behavior and decision-making process should be carried out. As there is a very limited amount of research that has strictly been listed and focuses on Neuromarketing. With this basic introduction, the perspective of social science will shed light on the need for new researchers to begin their work on Neuromarketing. The future of marketing is bright with the implementation of neuromarketing; researchers and marketers will strategize and develop smarter marketing that will increase the efficacy of their marketing activities.

Acknowledgments: The authors would like to acknowledge the Faculty of Business and Management (UiTM), Graduate School of Business (USM), and Skim Latihan Akademik IPTA (SLAI) by Kementerian Pendidikan Tinggi Malaysia for funding and supporting this study.

Author Contributions: Both authors contributed to the idea, interpretation, writing and revision of the article.

Conflicts of Interest: The authors declare no conflict of interest.

\section{References}

Agarwal, S., \& Dutta, T. (2015). Neuromarketing and consumer neuroscience: Current understanding and the way forward. DECISION, 42(4), 457-462. https://doi.org/10.1007/s40622-015-0113-1

Al-Kwifi, S. O. (2016). The role of $\mathrm{fMRI}$ in detecting attitude toward brand switching: An exploratory study using high technology products. Journal of Product \& Brand Management, 25(2), 208-218. https://doi.org/10.1108/jpbm-12-2014$\underline{0774}$

Ariely, D., \& Berns, G. S. (2010). Neuromarketing: The hope and hype of neuroimaging in business. Nature Reviews Neuroscience, 11(4), 284-292. https://doi.org/10.1038/nrn2795

Arlauskaitè, E., \& Sferle, A. (2013). Ethical issues in neuromarketing. Lund University.

Babu, S. S., \& Vidyasagar, T. P. (2012). Neuromarketing: Is Campbell in Soup? The IUP Journal of Marketing Management, $X I(2), 76-100$.

Bebko, C., Sciulli, L. M., \& Bhagat, P. (2014). Using eye tracking to assess the impact of advertising appeals on donor behavior. Journal of Nonprofit \& Public Sector Marketing, 26(4), 354-371. https://doi.org/10.1080/10495142.2014.965073

Bercea, M. D. (2012). Anatomy of methodologies for measuring consumer behavior in neuromarketing research. $L C B R$ European Marketing Conference, Munich, Germany.

Colaferro, C. A., \& Crescitelli, E. (2014). The contribution of Neuromarketing to the study of consumer behavior. Brazilian Business Review, 11(3), 123-143. https://doi.org/10.15728/bbr.2014.11.3.6

Calvert, G. A., \& Brammer, M. J. (2012). Predicting consumer behavior: Using novel mind-reading approaches. IEEE Pulse, 3(3), 38-41. https://doi.org/10.1109/mpul.2012.2189167

Calvert, G. (2014, December 12). How neuromarketing can unlock cross-cultural understanding. Green Future Magazines. http://www.forumforthefuture.org/greenfutures/articles/how-neuromarketing-can-unlock-cross-cultural-understanding

Clement, J., Smith, V., Zlatev, J., Gidlöf, K., \& Weijer, J. van de. (2017). Assessing information on food packages. European Journal of Marketing, 51(1), 219-237. http://doi.org/10.1108/EJM-09-2013-0509

Fehse, K., Simmank, F., Gutyrchik, E., \& Sztrókay-Gaul, A. (2017). Organic or popular brands-food perception engages distinct functional pathways. An fMRI study. Cogent Psychology, 4(1), 1284392. 
https://doi.org/10.1080/23311908.2017.1284392

Fisher, C. E., Chin, L., \& Klitzman, R. (2010). Defining Neuromarketing: Practices and professional challenges. Harvard Review of Psychiatry, 18(4), 230-237. https://doi.org/10.3109/10673229.2010.496623

Fugate, D. L. (2007). Neuromarketing: A Layman's look at neuroscience and its potential application to marketing practice. Journal of Consumer Marketing, 24(7), 385-394. https://doi.org/10.1108/07363760710834807

Genco, S., Pohlmann, A., \& Steidl, P. (2013). Neuromarketing For Dummies. Mississauga: John Wiley \& Sons, Inc.

Gidlöf, K., Wallin, A., Dewhurst, R., \& Holmqvist, K. (2013). Using eye tracking to trace a cognitive process: Gaze behaviour during decision making in a natural environment. Journal of Eye Movement Research, 6(1), 1-14.

https://doi.org/10.16910/jemr.6.1.3

Hensel, D., lorga, A., Wolter, L., \& Znanewitz, J. (2017). Conducting neuromarketing studies ethically-practitioner perspectives. Cogent Psychology, 4(1), 1320858. https://doi.org/10.1080/23311908.2017.1320858

Hubert, M., \& Kenning, P. (2008). A current overview of consumer neuroscience. Journal of Consumer Behaviour, 7(4-5), 272292. https://doi.org/10.1002/cb.251

Javor, A., Koller, M., Lee, N., Chamberlain, L., \& Ransmayr, G. (2013). Neuromarketing and consumer neuroscience: Contributions to neurology. BMC Neurology, 13(1), 13. https://doi.org/10.1186/1471-2377-13-13

Kenning, P., Plassmann, H., \& Ahlert, D. (2007). Applications of functional magnetic resonance imaging for market research. Qualitative Market Research: An International Journal, 10(2), 135-152. https://doi.org/10.1108/13522750710740817

Khushaba, R. N., Wise, C., Kodagoda, S., Louviere, J., Kahn, B. E., \& Townsend, C. (2013). Consumer neuroscience: Assessing the brain response to marketing stimuli using electroencephalogram (EEG) and eye tracking. Expert Systems with Applications, 40(9), 3803-3812. https://doi.org/10.1016/i.eswa.2012.12.095

Kühn, S., Strelow, E., \& Gallinat, J. (2016). Multiple "buy buttons" in the brain: Forecasting chocolate sales at point-of-sale based on functional brain activation using fMRI. Neurolmage, 136, 122-128. https://doi.org/10.1016/j.neuroimage.2016.05.021

Lee, N., Broderick, A. J., \& Chamberlain, L. (2007). What is 'neuromarketing'? A discussion and agenda for future research. International Journal of Psychophysiology, 63(2), 199-204. https://doi.org/10.1016/j.ijpsycho.2006.03.007

Lepping, R. J., Papa, V. B., \& Martin, L. E. (2015). Cognitive neuroscience perspectives on food decision-making: A brief introduction. Journal of Agricultural \& Food Industrial Organization, 13(1), 5-14. https://doi.org/10.1515/jafio-2015-0026

Lewis, D., \& Bridger, D. (2005). Market Researchers make Increasing use of Brain Imaging. Advances in Clinical Neuroscience and Rehabilitation, 5(3), 36-37.

Lim, W. M. (2018). Demystifying neuromarketing. Journal of Business Research, 91, 205-220. https://doi.org/10.1016/j.jbusres.2018.05.036

Lowenstein, M. (2019, September 30). Feelings and emotional underpinnings: What are their real implications in the B2B and B2C customer experience journey? CX Consulting. https://beyondphilosophy.com/feelings-emotional-underpinnings-realimplications-b2b-b2c-customer-experience-journey/

McClure, S. M., Li, J., Tomlin, D., Cypert, K. S., Montague, L. M., \& Montague, P. (2004). Neural correlates of behavioral preference for culturally familiar drinks. Neuron, 44(2), 379-387. https://doi.org/10.1016/j.neuron.2004.09.019

McDowell, W. S., \& Dick, S. J. (2013). The marketing of Neuromarketing: Brand differentiation strategies employed by prominent Neuromarketing firms to attract media clients. Journal of Media Business Studies, 10(1), 25-40. https://doi.org/10.1080/16522354.2013.11073558

Mostafa, M. M. (2014). Functional neuroimaging applications in marketing: Some methodological and statistical considerations. Qualitative Market Research: An International Journal, 17(4), 343-372. https://doi.org/10.1108/amr-06$\underline{\text { 2011-0003 }}$

Nyoni, T., \& Bonga, W. G. (2017). Neuromarketing: No brain, No Gain! Journal of Economics and Finance (DRJ-JEF), 2(2), 1729.

Ohme, R., Reykowska, D., Wiener, D., \& Choromanska, A. (2010). Application of frontal EEG asymmetry to advertising research. Journal of Economic Psychology, 31(5), 785-793. https://doi.org/10.1016/j.joep.2010.03.008

Oliveira, J. H., Giraldi, J. D., \& Santos, R. D. (2014). Opening the "black box" in the consumer's mind: Understanding what is Neuromarketing. International Journal of Business and Management, 9(9), 97-107. https://doi.org/10.5539/ijbm.v9n9p96

Palokangas, L., Jyrki, S., Jarmo, H., Sini, M., \& Jussi, N. (2012). Measuring the Willingness To Purchase using methods of neuromarketing. Laurea University of Applied Sciences.

Ravaja, N., Somervuori, O., \& Salminen, M. (2013). Predicting purchase decision: The role of hemispheric asymmetry over the frontal cortex. Journal of Neuroscience, Psychology, and Economics, 6(1), 1-13. https://doi.org/10.1037/a0029949

Rehman, S. M. ur, Shamsi, A. F., Rehman, S. S. ur, Ali, M. A., \& Faraz, M. (2016). Neuro Marketing: A Qualitative Analysis Of A Manager's Perception In Pakistan. Elk Asia Pacific Journal Of Marketing And Retail Management, 7(3), 1-11.

Reutskaja, E., Nagel, R., Camerer, C. F., \& Rangel, A. (2011). Search dynamics in consumer choice under time pressure: An eye-tracking study. American Economic Review, 101(2), 900-926. https://doi.org/10.1257/aer.101.2.900

Samsuri, N., Reza, F., Begum, T., Yusoff, N., Idris, B., Omar, H., \& Mohd Isa, S. (2018). Application of EEG/ERP and eye tracking in underlying mechanism of visual attention of auto dealer's advertisement - A Neuromarketing research. International 
Journal of Engineering \& Technology, 7(3.22), 5. https://doi.org/10.14419/ijet.v7i3.22.17112

Sands, S. F., \& Sands, J. A. (2012). Recording brain waves at the supermarket: What can we learn from a shopper's brain? IEEE Pulse, 3(3), 34-37. https://doi.org/10.1109/mpul.2012.2189170

Sebastian, V. (2014). Neuromarketing and evaluation of cognitive and emotional responses of consumers to marketing stimuli. Procedia - Social and Behavioral Sciences, 127, 753-757. https://doi.org/10.1016/j.sbspro.2014.03.349

Slavutskaya, M. V., Moiseeva, V. V., Kotenev, A. V., Karelin, S. A., \& Shulgovskiy, V. V. (2014). EEG correlates of decisionmaking and preparation of saccades in human. GSTF International Journal of Psychology, 1(1), 68-73.

https://doi.org/10.7603/s40790-014-0010-7

Spanjaard, D., Young, L., \& Freeman, L. (2014). Emotions in supermarket brand choice. Qualitative Market Research: An International Journal, 17(3), 209-224. https://doi.org/10.1108/qmr-10-2012-0049

Steidl, P. (2012, October 2). Neuromarketing: Marketing fad or marketing. WebWire. https://www.webwire.com/ViewPressRel.asp?ald=161710

Suomala, J., Palokangas, L., Leminen, S., Westerlund, M., Heinonen, J., \& Numminen, J. (2012). Neuromarketing: Understanding customers' subconscious responses to marketing. Technology Innovation Management Review, 2(12), 1221. https://doi.org/10.22215/timreview/634

Sutherland, M. (2007, March 1). Neuromarketing: What's it all about? https://www.sutherlandsurvey.com

Telpaz, A., Webb, R., \& Levy, D. J. (2015). Using EEG to predict consumers' future choices. Journal of Marketing Research, 52(4), 511-529. https://doi.org/10.1509/jmr.13.0564

Vecchiato, G., Astolfi, L., De Vico Fallani, F., Toppi, J., Aloise, F., Bez, F., Wei, D., Kong, W., Dai, J., Cincotti, F., Mattia, D., \& Babiloni, F. (2011a). On the use of EEG or MEG brain imaging tools in Neuromarketing research. Computational Intelligence and Neuroscience, 2011, 1-12. https://doi.org/10.1155/2011/643489

Vecchiato, G., Toppi, J., Astolfi, L., De Vico Fallani, F., Cincotti, F., Mattia, D., Bez, F., \& Babiloni, F. (2011b). Spectral EEG frontal asymmetries correlate with the experienced pleasantness of TV commercial advertisements. Medical \& Biological Engineering \& Computing, 49(5), 579-583. https://doi.org/10.1007/s11517-011-0747-x

Wilson, R., Gaines, J., \& Hill, R. P. (2008). Neuromarketing and consumer free will. Journal of Consumer Affairs, 42(3), 389410. https://doi.org/10.1111/j.1745-6606.2008.00114.x

Zurawicki, L. (2010). Neuromarketing: Exploring the brain of the consumer. Springer Science \& Business Media. 